\title{
札幌コンベンションセンター大ホールA SL-001 Understanding the Psychology of a Cultural Species
}

\author{
講演者 : Joseph Henrich (University of British Columbia) \\ 司会者: 亀田 達也 (北海道大学)
}

\section{講演の内容}

Long before the origins of agriculture, our species had spread from the frozen tundra of Siberia to the arid deserts of Australia. The secret of our immense ecological success lies neither in the intelligence of individuals nor in an array of local genetic adaptations. Instead, unlike other species, humans are entirely dependent on large bodies of culturally-transmitted information that accumulate over generations in ways that build complex non-genetic adaptations to local environmental challenges. Drawing on evolutionary modeling, crosscultural and cross-species comparisons, laboratory experiments on social learning, and quantitative ethnographic work in diverse small-scale societies, I argue that our species' long reliance on this second system of inheritance, and its ever accumulating and complex adaptive products, has driven the expansion of human brains while shaping our cognitive abilities, manual dexterity, status psychology, gut size, and social inclinations. Hundreds of thousands of years of this culture-gene coevolutionary process produced modern humans, the world's only cultural species. Broadly, this research program suggests not only that understanding human evolution requires considering the interaction between genetic and cultural inheritance systems, but also that building a scientific research program in psychology requires considering this unique evolutionary history. Psychology, as a discipline, is currently poorly equipped to tackle this challenge.

\section{略歴}

Dr. Henrich holds the Canada Research Chair in Culture, Cognition and Coevolution at the University of British Columbia, where he's a professor in both Economics and Psychology. He received his PhD in Anthropology from UCLA in 1999. His theoretical work focuses on how natural selection has shaped human learning and how this in turn influences cultural evolution and culture-gene coevolution. This work has explored the evolution of conformist learning and human status, as well as the emergence of large-scale cooperation, norms, social stratification, world religions and monogamous marriage. Methodologically, his research synthesizes experimental and analytical tools drawn from behavioural economics and psychology with in-depth quantitative ethnography, and he has performed long-term anthropological fieldwork in the Peruvian Amazon, rural Chile, and in the South Pacific. His work has been published in the top journals in biology, psychology, anthropology and economics, including Science, Nature, PNAS, Behavioral and Brain Sciences, Proceedings of the Royal Society B, Psychological Science, Cognition, American Economic Review, Current Anthropology, Animal Behavior and Trends in Cognitive Science. In 2004 he was awarded the Presidential Early Career Award, the highest award bestowed by the United States upon scientists early in their careers. In 2009, the Human Behavior and Evolution Society awarded him their Early Career Award for Distinguished Scientific Contributions. Dr. Henrich is a fellow at the Canadian Institute for Advanced Research, and is currently holds the Peter and Charlotte Schoenenfeld Visiting Faculty Fellowship at the NYU Stern School of Business.

\section{主な著書・論文}

Project-based Edited Volumes

Ensminger, J. and J. Henrich (forthcoming) Experimenting with Social Norms: Fairness and Punishment in Cross-Cultural Perspective. Russell Sage Foundation Press

Henrich, J., R. Boyd, S. Bowles, H. Gintis E. Fehr, C. Camerer (editors) (2004) Foundations of Human Sociality: Ethnography and Monograph Experiments in 15 small-scale societies. Oxford University Press.

Henrich, N. and J. Henrich (2007) Why Humans Cooperate: A cultural and evolutionary explanation. Oxford University Press. Journal Articles

1) Bauer, M., Cassar A., Chytilová, J. and J. Henrich (forthcoming) War's Enduring Effects on the Development of Egalitarian Motivations and In-group Biases. Psychological Science

2) Cheng, J. T., Tracy, J. L., Foulsham, T., \& Kingstone, A., \& J. Henrich (2013). Two Ways to the Top: Evidence that Dominance and Prestige are Distinct yet Viable Avenues to Social Rank and Influence. Journal of Personality and Social Psychology, 104: 103125 .

3) Henrich, J., R. Boyd and P. J. Richerson (2012) The Puzzle of Monogamous Marriage. Philosophical Transactions of the Royal Society B: Biological Sciences 367: 657-669.

4) Chudek, M. Heller, S., Birch, S. and J. Henrich (2012) Prestige-Biased Cultural Learning: Bystander's Differential Attention to Potential Models Influences Children's Learning. Evolution and Human Behavior 33, 46-56.

5) Boyd, R., Richerson, P., J., Henrich (2011) The Cultural Niche. Proceedings of the National Academy of Sciences of the United States 108: 10918-10925. 
6) Chudek, M. and J. Henrich (2011) Culture-gene coevolution, norm-psychology and the emergence of human prosociality. Trends in Cognitive Sciences 15(5): 218-226.

7) Henrich, J. and N. Henrich (2010) The Evolution of Cultural Adaptations: Fijian taboos during pregnancy and lactation protect against marine toxins. Proceedings of the Royal Society B: Biological Sciences 277: 3715-3724.

8) Henrich, J., S. Heine and A. Norenzayan (2010) The Weirdest People in the World. Behavioral and Brain Sciences [Target Article] 33: $1-23$

9) Atran, S. and J. Henrich (2010) The Evolution of Religion. Biological Theory: Integrating Development, Evolution and Cognition 5(1): 18-30.

10) Richerson, P. J., R. Boyd, and J. Henrich (2010) Gene-Culture Coevolution in the Age of Genomics. Proceedings of the National Academy of Science of the United States 107: 8985-8992.

11) Henrich, J., J. Ensminger, R. McElreath, A. Barr, H. C. Barrett, A. Bolyanatz, J. Camilo Cardenas, M. Gurven, E. Gwako, N. Henrich, C. Lesorogol, F.W. Marlowe, D. Tracer, J. Ziker (2010) Markets, religion, community size and the evolution of fairness and punishment, Science 327: 1480-1484.

12) Henrich, J. (2009) The evolution of costly displays, cooperation, and religion. Evolution and Human Behavior 30: 244-260.

13) Henrich, J., R. Boyd, and P. J. Richerson (2008) Five Misunderstandings about Cultural Evolution, Human Nature 19:119-137.

14) Henrich, J., McElreath, R., Barr, A., Ensimger, J. Barrett, H. C., Bolyanatz, A., Camilo Cardenas, J. Gurven, M., Gwako, E. Henrich, N., Lesorogol, C., Marlowe, F. W. Tracer, D., and J. Ziker (2006) Costly Punishment Across Human Societies, Science 312: 1767- 1770.

15) Henrich, J., Boyd, R., Bowles, S., Gintis, H., Fehr, E., Camerer, C., McElreath, R., Gurven, M., Hill, K., Barr, A., Ensminger, J., Tracer, D., Marlow, F. W., Patton, J., Alvard, M., Gil-White, F. and N. Smith (2005) "Economic Man" in cross-cultural perspective: Behavioral experiments from 15 small-scale societies. Behavioral and Brain Sciences [Target article] 28: 795-815 (Target Article includes 23 commentaries).

16) Silk, J. B., Brosnan, S. F., Vonk, J., Henrich, J., Povinelli, D. J., Richardson, A., Lambeth S. P., Mascaro, J. \& S. J. Shapiro (2005) Chimpanzees are indifferent to the welfare of unrelated group members. Nature 437, 1357-1359.

17) Henrich, J. (2004) Demography and Cultural Evolution: Why adaptive cultural processes produced maladaptive losses in Tasmania. American Antiquity 69 (2): 197-214.

18) Henrich, J. (2004) Cultural Group Selection, coevolutionary processes and large-scale cooperation. Journal of Economic Behavior and Organization [target article] 53: 3-35.

19) Henrich, J. and R. Boyd (2001) Why people punish defectors: conformist transmission stabilizes costly enforcement of norms in cooperative dilemmas. Journal of Theoretical Biology 208, 79-89.

20) Henrich, J. \& F. Gil-White (2001) The Evolution of Prestige: freely conferred status as a mechanism for enhancing the benefits of cultural transmission. Evolution and Human Behavior, 22, 1-32. 